\title{
Article \\ Strategic Management of the Malaga Brand through Open Innovation: Tourists and Residents' Perception
}

\author{
Elena Cruz-Ruiz ${ }^{1}$ (D), Elena Ruiz-Romero de la Cruz ${ }^{2, * \mathbb{D}}$, Gorka Zamarreño-Aramendia ${ }^{2} \mathbb{D}$ and F. J. Cristòfol $^{3}$ (D) \\ 1 Department of Economics and Business Administration, University Malaga, 29013 Malaga, Spain; \\ ecruz@uma.es \\ 2 Department of Theory and Economic History, University Malaga, 29013 Malaga, Spain; gzama@uma.es \\ 3 Market Research and Quantitative Methods Department, ESIC, Business \& Marketing School, \\ Pozuelo de Alarcón, 28223 Madrid, Spain; fjcristofol@esic.edu \\ * Correspondence: emruiz@uma.es
}

Citation: Cruz-Ruiz, E.; Ruiz-Romero de la Cruz, E.; Zamarreño-Aramendia, G.; Cristòfol, FJ. Strategic Management of the Malaga Brand through Open Innovation: Tourists and Residents' Perception. J. Open Innov. Technol. Mark. Complex. 2022, 8, 28. https://doi.org/10.3390/ joitmc 8010028

Received: 30 December 2021

Accepted: 17 January 2022

Published: 20 January 2022

Publisher's Note: MDPI stays neutral with regard to jurisdictional claims in published maps and institutional affiliations.

Copyright: (C) 2022 by the authors. Licensee MDPI, Basel, Switzerland. This article is an open access article distributed under the terms and conditions of the Creative Commons Attribution (CC BY) license (https:// creativecommons.org/licenses/by/ $4.0 /)$.

\begin{abstract}
Territory brands are vehicles for transmitting the attributes that identify a geographical setting, they facilitate market positioning and can contribute to generating an opinion that determines the promotion strategies of a place. The investment decisions of both private companies and institutional bodies will be strengthened if residents and tourists' perception is known, seeking to reconcile the interests of visitors and citizens with the aim of collaborating in the creation of the city's tourism planning under the principles of sustainability, open innovation and co-creation of value. The methodology used for this research focuses on an empirical study, for which a sample of 780 individuals was designed so that the Malaga brand was subjected to analysis with criteria of innovative opportunity, applying constructs that were measured with existing and proven scales. The results allow us to identify that the Malaga brand is being built and managed on the basis of the cultural projection of the city and its image attributes. The ratings of tourists and residents will serve as a basis for improving the management of Malaga as a tourist destination by the institutions involved, taking into account the interest of open innovation. The conclusions of the research can be extrapolated to other geographical environments with similar levels of tourism development.
\end{abstract}

Keywords: open innovation; city branding; place branding; stakeholder management; sustainability

\section{Introduction}

The city is a melting pot that brings together the cosmopolitan and the provincial [1]. It is a place where cultural institutions and businesses that serve the leisure of the local population and the tourist [2] are based, functioning as global and undifferentiated hubs [3]. Urban economic development is driven by service industries and innovation, where quality of life, infrastructure and creative image play a mutually reinforcing role in the attractiveness of cities and tourism [4].

It is said that a city that aspires to its success as a destination must take into account all parts involved, such as residents, tourists and businesses [5], thus making cities more sustainable in the long term [6,7].

In this dynamic, traditional styles of sociability and consumption give way to the push for integration, which is gradually imposing itself on the leisure practices of the residents themselves, generating spaces of hybridisation [8] and a new perception of city identity, which has a direct impact on the city as a brand [9].

In this new context of modernity and social coexistence between tourists and residents, residents' perceptions must be considered, as a positive image of the city can contribute to tourism development and affect the overall tourism experience [10,11]. The self-image of the destination as perceived by its residents has a significant effect on tourist arrivals $[12,13]$.

Similarly, tourists' perception is relevant to achieve the objective of projecting an image in accordance with their needs and desires. In addition, tourists increasingly travel with 
the intention of learning about the daily life of the local population in order to enhance their travel experience [14-16].

It is precisely the integration of both approaches that favours the sustainable development of cities $[17,18]$. In a way, the search for common and shared ground improves the perception of the environment when tourism is approached as part of the city's identity [19].

If city image perception studies for residents have been frequent [10,20-22], analyses of tourist perception have been more infrequent, [23-27], and the conjunction of both is a less addressed issue, although in recent years research is already underway on a model contemplating both views [22] applied to case studies such as the analysis for the north of India [28-30].

The perceptions and experiences of tourists and residents need to be taken into account for sustainable urban planning and its implications for tourism development [31], as cities share entertainment spots such as restaurants, stores or museums, producing complex scenarios that are considered crucial by both local residents and out-of-town visitors [1], where it is difficult to guess who is on holiday and who is in their city, who is a resident and who is an outsider.

Moreover, the evolution of tourism governance is renewed and each agent brings valuable resources to the whole [32], leading to a more distributed leadership [33,34].

It is precisely the increasing competition between cities that drives management agencies to look to brands as a vehicle that can generate the desire to get to know and visit a city. Today, the role that brands can play in this stage, which requires the recovery of tourism normality, will be fundamental in the wake of the crisis caused by COVID-19, and tourism governance is becoming essential [32].

At this critical crossroads, the managers of the city brand will have to implement and carry out an exercise of open innovation, developing new strategies that seek to unify the promotional actions of the territory, turning the brand into a main asset [35], transferring this concept of city to a new global sphere of legitimate competition between territories [36], and improving its competitive position [37] and as a vector for international projection [38], with the participation of companies and institutions.

The diversity of groups found in cities that give their opinion on social media means that the content generated and analysed can contribute to tourism innovation [39]. Another way to contribute to this innovation is through the perception of the brands of the cities that serve to promote them and allow recognition of the values and symbols of a territory. In addition, how they discriminate some places from other similar ones can be used to identify it $[40,41]$, where the principles of sustainability, open innovation and co-creation of value are taken into account [42-44].

This research has sought precisely to analyse Malaga as a brand taking into account the agents involved with a view to being able to transfer its findings to the companies that offer their services and to the institutions themselves that are responsible for managing the territory. The novelty of the study is that it will be analysed through the connotations that can be perceived through its brand, considering the opinion of residents and tourists.

Companies and administrations must adapt to and assume the changes that arise from the use of technologies. Along these lines, public administrations can also manage open innovation processes to improve the planning of their strategic policies, as pointed out by [45].

Malaga has been chosen because it is a city known worldwide for its tourism. It is not exactly a large city and therefore its study requires interest, as pointed out by [21], who state there is a need to evaluate the image of small and medium-sized cities, and not only large capitals.

This paper has the following structure, starting with an introduction that brings us closer to the proposed topic, which is the perception of residents and tourists about the city of Malaga as a brand. Section 2 provides the theoretical background based on the concept and model of open innovation and the analysis of the city brand as a basis for better governance of the city, taking into account the brand's capacity to transmit value. Section 3 
shows the methodology applied and the questionnaire used. The results are presented in Section 4, followed by the discussion in Section 5. Finally, the conclusions, implications and limitations of the research are set out in Section 6.

This research is based on a case study based on the city of Malaga and its city brand; however, it is understood that this is an interesting and relevant topic, little treated in the academic literature related to open innovation.

The research has the following objectives:

1. Understanding how inhabitants perceive the city brand through a specific case study focused on Malaga (Spain).

2. Considering whether or not this perception is similar to the perception of tourists.

3. Recognising whether citizens participate in the process of promoting and identifying the brand of the city in which they live.

4. Observing the business options that allow, through a process of open innovation, promotion of the city to be improved through its brand.

The research questions that have been posed are:

RQ 1: How can the management of the territory brand benefit from open innovation (OI) strategies in the tourism sector?

RQ 2: Which economic sectors benefit from OI strategies from the Malaga brand?

RQ 3: What should be the role of the public administration in the management of OI strategies in the Malaga brand?

The interest of the research focuses on the relative scarcity of similar studies that analyse the possibilities offered by OI processes from the perspective of tourists and citizens. There are some relevant methodological proposals [46]. An analysis of the possibilities of OI in tourism has been addressed by [47], while some studies have been advanced mainly on consolidated tourism models [48-51], which makes case studies such as the one presented here even more relevant.

\section{Review of the Academic Literature}

Territorial branding is a perceptual tool capable of defending the differential values of a place in relation to other places. In simple terms, we could define the image of a territory as the idea of perception that the rest of the world has of this territory [52]. Its purpose is to add value to a singular identity, which will allow a certain positioning to be achieved [53]. The practice of place branding must be based on three fundamental assumptions: the identity of the place, the image of the place and the consumer experience of the place [42].

Brands reinforce the unique image of a place in the minds of the parties involved, whether they live there or may experience it as tourists and visitors. Therefore, we will be talking about residents and tourists, as well as storekeepers and businesses [21], generating a sense of trust and a strong local identity [54-59].

\subsection{Concept of Open Innovation}

Open innovation is a concept based on innovative management. It is a practical model based on collaboration between people and organisations both inside and outside the company [60]. One of the most relevant challenges of this concept of open innovation is how to bridge the gap between the organisation's know-how and the traditional secret link with corporate R\&D.

In this area of open innovation, organisations should consider the option of coproducing with external professionals and organisations, sharing benefits and new practices that are derived in a complementary way from a shared work process. Therefore, we are talking about a collaboration that goes beyond the boundaries of organisations and fills the market with their benefits [61].

Open innovation means, on the one hand, the use of external knowledge sources to accelerate internal innovation and, on the other hand, the use of external ways to reach the internal knowledge market. Open innovation is a holistic approach to innovation 
management by "systematically encouraging and exploring a wide range of internal and external sources of innovation opportunities, consciously integrating such exploration with the firm's capabilities and resources, and comprehensively exploiting these opportunities through multiple channels" [62].

The concept of open innovation has moved from the triple helix to the quadruple helix as a model with which to identify connections across different stakeholders. According to [63], the triple helix model shows a non-linear model of innovation through interactions between universities, industries and government policies. The model proposed in this paper is based on the four-helix model (shown in Figure 1), including civil society, crowds strongly influenced by cultural contexts and the media.

The model combines top-down policies and bottom-up grassroots initiatives, cocreating knowledge and value, which can be applied to both developed and developing economies $[64,65]$.

The mechanism described here presents an adaptation to the specific need that has to take into account the values of branding, among which several elements stand out. City branding is an approach for the development of sustainable cities, improving the marketing of the city image and turning its visual image into a brand image. It highlights the unique characteristics of the city and creates a sustainable urban image [37].

Firstly, there is sustainability, which has been placed at the top of the environmental concerns agenda of both public and private institutions. Indeed, as Ishaq and Di Maria [66] point out, ecological and sustainability dimensions can be useful in two respects: they mitigate consumer cynicism about environmental issues and brand functionality, and they add value to the conceptualisation of brand equity. Similarly, brand building must be done from a sustainability paradigm distinct from marketing assets and the value that stakeholders place on it in the brand-building process.

A second milestone corresponds to the fulfilment of the UN Sustainable Development Goals that have shaped the rhetorical strategies of cities and countries, pending how the SDGs influence place development practices around the world in the future and the dilemma faced by tourist-receiving markets in creating their place branding (and city branding by extension), as pointed out by Marsden and Smith [67] and Maheshwari, Vandewalle and Bamber [68]. The ability to balance sometimes conflicting market interests can be accentuated in SDG-based place branding because fundamental preconditions for people's lives are at stake [69].

The sustainability of city brands is one of the most important strategic keys to the success of destinations [70]. Most cities seek to reinforce their visual image in order to achieve a sustainable urban image by integrating non-physical elements that are part of the tangible and intangible heritage. As Insch [71] states, the sensory elements of cities can serve as differentiation mechanisms in an increasingly uniform city brand landscape, hence the interest in making these heritage elements sustainable so that they last over time and form part of the concept of "atmosphere" [72] with which the city brand is endowed as a differentiating element.

Long-term collaboration would allow for improvement and more efficient production of services, while expanding customer knowledge [73]. The paper reveals that the success of the Porto brand is a result not only of its creative design, but also of the involvement of stakeholders in the region, in particular the strong and continuous commitment of civil society to the project. The final result reinforces the importance of open innovation in the process of sustainable development and the construction of the desired future [74]. 


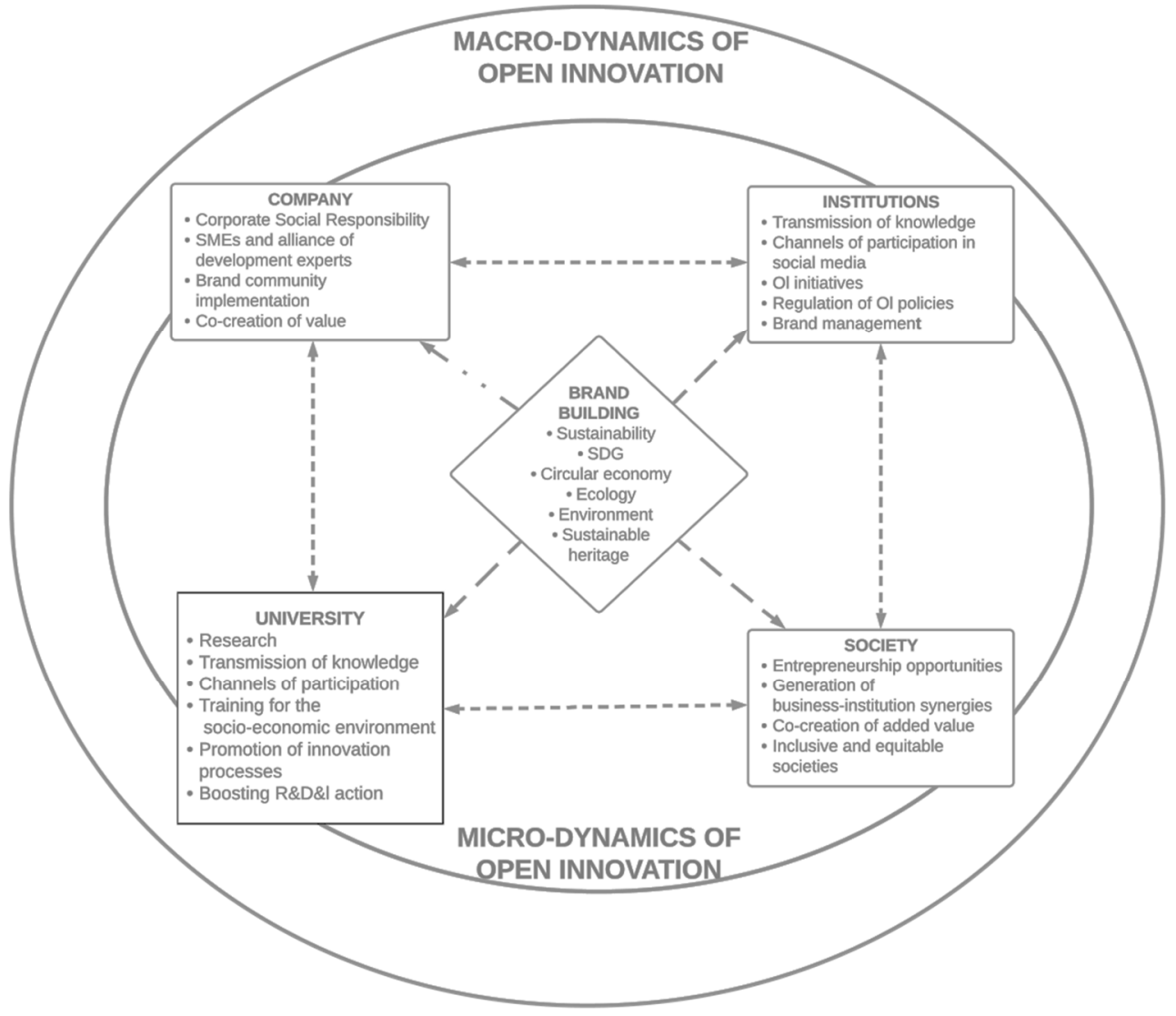

Figure 1. Quadruple helix model of open innovation. Carayannis and Campbell [75] and Yun and Liu [63]. Own elaboration.

\subsection{Transmission of Traditional Brand Values and Governance}

Brand equity is a set of assets and liabilities linked to the brand, its name and symbol, which incorporate or diminish the value provided by a product or service exchanged with the company's customers. The assets or liabilities are understood to be those that are actually linked to the brand name or symbol. If the brand name or symbol were changed, some of these assets or liabilities would be affected and even lost, although some could be used for the new names or symbols. According to Schultz and Schultz [76], the assets and liabilities on which brand equity is based differ from one context to another. However, they could be grouped into five categories: brand loyalty, name recognition, perceived quality, brand associations and, in addition to perceived quality, other brand assets: patent, trademarks, channel relationships, etc.

Schultz and Schultz [76] go on to say that there is a new paradigm whereby the company is oriented towards the consumer and not—as before-towards the product. This change implies a radical modification in the way companies and brands understand, conceive, and apply their strategies. In other words, focusing on the consumer means questioning the traditional model of the value chain, where each department worked focused on its operational needs. This new focus on the market, rather than on production, means that the marketing and communication departments have to take on a more central role within the organisation, focusing the strategy on the consumers and on satisfying their needs.

In this sense, communication between organisations and their stakeholders must be carried out in such a way that it reaches the greatest number of potential consumers at the lowest possible cost [77]. The importance of companies listening to their stakeholders-as we have previously mentioned with the ClueTrain Manifesto-has been increased both by new technological tools and by the number of options available to consumers in the market, as pointed out by Spengler and Muller [78]. 
For the theorists McLuhan and Fiore [79], the medium is the message. That is, as Schultz and Schultz [76] later point out the medium of transmission of the message will be decisive in persuasiveness, receptivity and responsiveness. Each medium chosen to reach stakeholders must be properly analysed to align it with the overall brand communication strategy.

In general, local governments should align their city branding strategies with their development objectives; actions taken at the institutional level provide insight into the real value of a city's image as opposed to other similar destinations. However, local governments must allow stakeholders in the brand building process to express their needs, so open participation is one of the key issues to achieve a successful implementation of the desired brand [80].

\section{Materials and Methods}

The research carried out is based on a study carried out by the SEJ 121 research group "Mediterráneo económico", belonging to the University of Malaga. A survey was carried out in person in the different districts of the city of Malaga.

The objectives of the research and the research questions posed required information gathered through a questionnaire, which collected data on the perception of the Malaga brand by residents and tourists. In this sense, we must define the questionnaire in terms of a research technique. According to Meneses and Rodríguez-Gómez [81], "a questionnaire is, by definition, the standardised tool that we use for data collection during the fieldwork of some quantitative research, fundamentally those carried out with survey methodologies". Therefore, the questionnaire is the tool used to conduct surveys.

The selected geographical framework corresponds to the city of Malaga, as can be seen in Figure 2, the capital of the province of Malaga, in the autonomous community of Andalusia, Spain. Malaga is the fifth most populated city in Spain. It is located in the south of the Iberian Peninsula, in a privileged spot. The city covers 398.25 square kilometres and has a population of almost 578,460 inhabitants, although almost a million people live in the metropolitan area. The survey was carried out by means of direct interviews with the participants. In the case of the inhabitants of Malaga (Spain), a multistage cluster sampling was developed, taking into account the values offered by the population register of 2019. In this way, the sample is directly proportional to the structure of the population over 18 years of age in the districts of Malaga (Figure 3). In the case of survey participants who are not residents, i.e., the category of visitors, the sample is based on data from the Tourism Tracker Project of the city of Malaga (2019). Thus, a simple random sampling was carried out.

The valid sample obtained is 780 questionnaires, of which 420 correspond to male and female residents in Malaga and 360 are questionnaires answered by visitors to the city. In all cases, the questionnaires were answered in person (Table 1). The purpose of the questionnaire was to gather information on the recognition of the city brand. Therefore, the questions are formulated in such a way that they are in line with the purpose of the study.

Table 1. Data collection method.

\begin{tabular}{cc}
\hline Data Collection Method & Multistage Cluster Sampling \\
\hline Sample size & 780 (420 residents +360 visitors $)$ \\
\hline Confidence level & $95 \%$ \\
\hline Sample error & $4.2 \%$ \\
\hline Place of data collection & City of Malaga \\
\hline Date of data collection & September-December (2019) \\
\hline
\end{tabular}




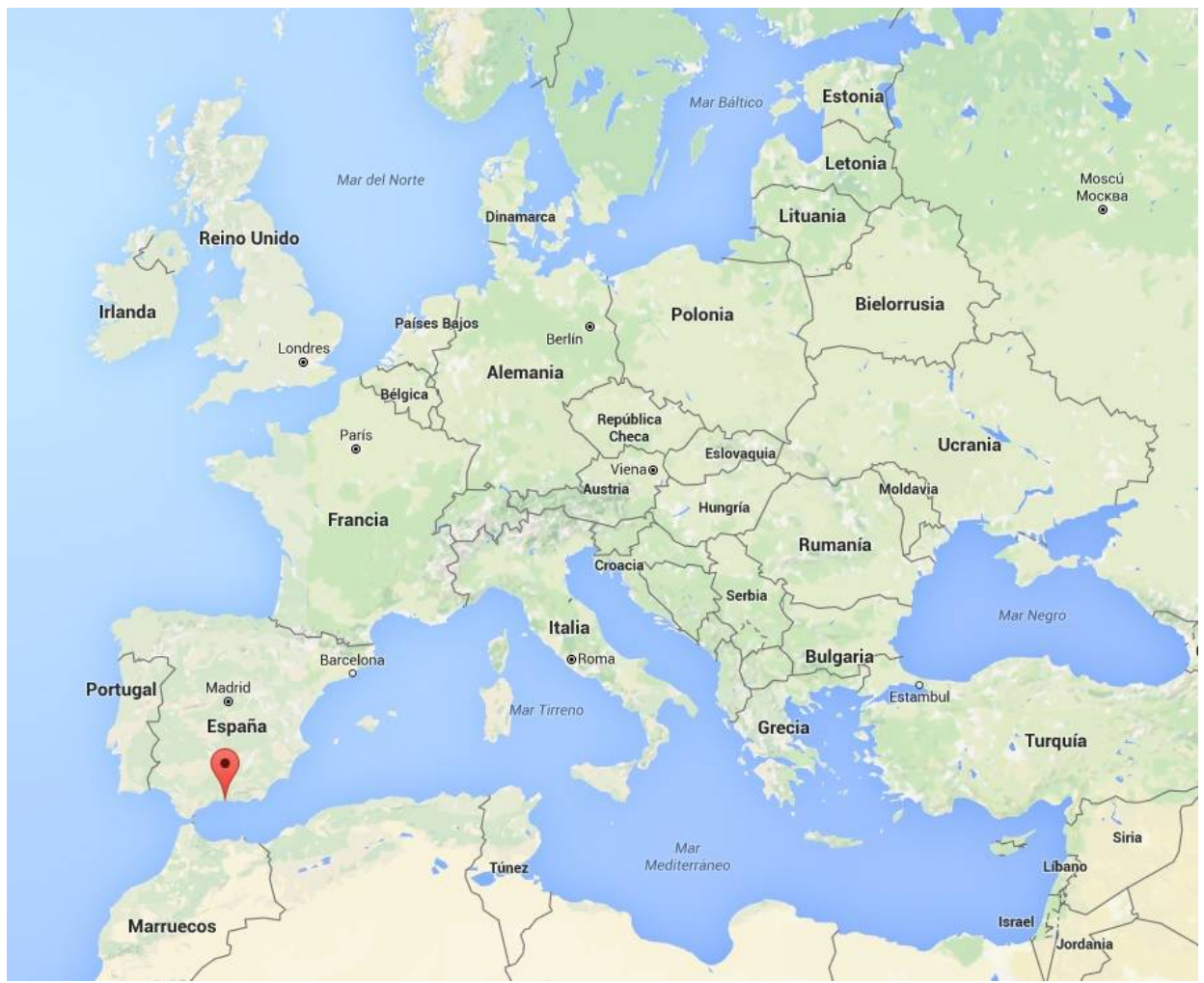

Figure 2. Malaga situation map. Source: own elaboration based on the digital cartography of the National Geographic Institute (IGN). Adapted with permission from ref. [82]. Copyright 2022 IGN.

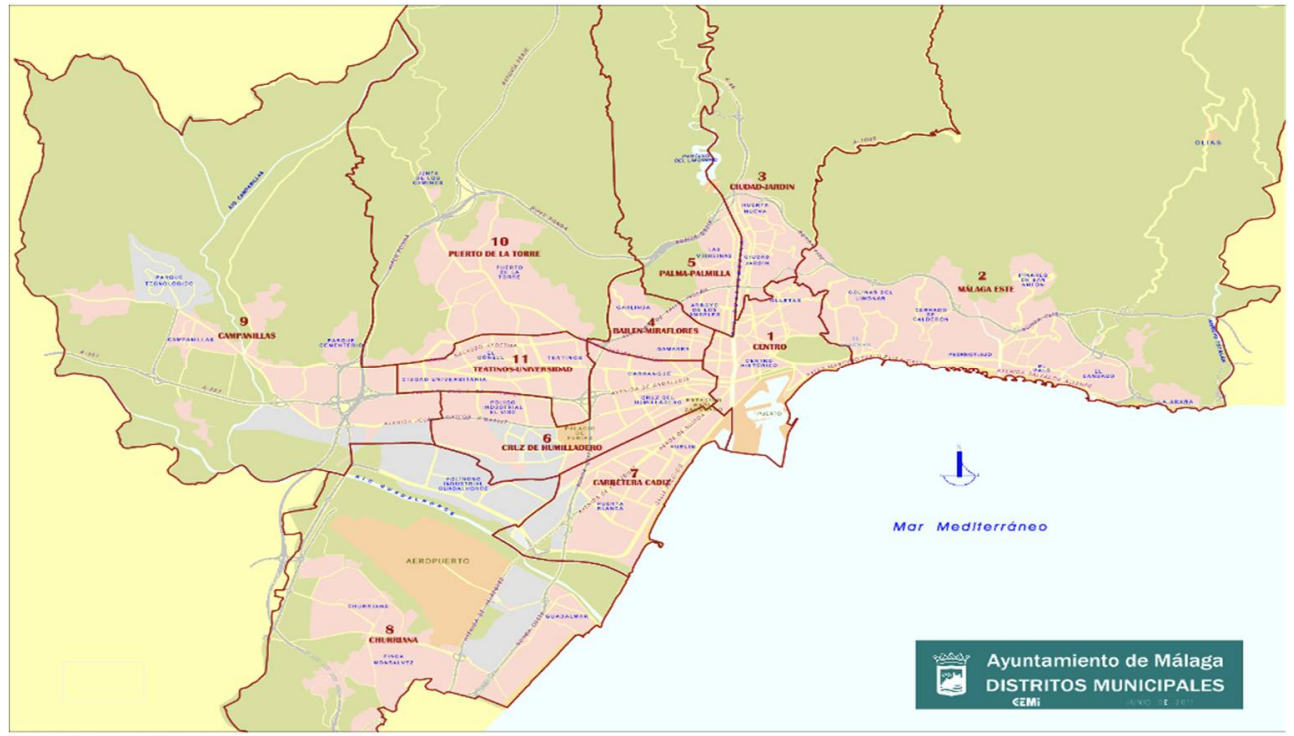

Figure 3. Map of municipal districts of Malaga. Source: Adapted with permission from ref. [83]. Copyright 2022 Ayuntamiento de Málaga.

Sample criteria: The sample of residents selected for the study corresponds to the division of the population into the following age groups, maintaining proportionality between genders according to the latest population census carried out in 2019: under 18 years; $18-35$ years; $36-55$ years; $56-75$ years; and finally, those over 76 years of age. With regard to the visitors, the criteria of proportionality were respected, so that a division was established by gender and place of origin (national, international), according to the data provided by the Tourism Tracker Project of the city of Malaga to proceed to a simple random 
sample in which 360 valid surveys were collected. The socio-demographic questions are summarised in Table 2.

Table 2. Socio-demographic characterisation of the interviewees. Own elaboration.

\begin{tabular}{|c|c|c|c|c|c|c|c|c|c|c|c|c|}
\hline \multirow[b]{3}{*}{ Gender } & \multicolumn{3}{|c|}{ Residents } & \multicolumn{9}{|c|}{ Visitors } \\
\hline & \multicolumn{3}{|c|}{$\mathrm{N}: 420$} & \multicolumn{9}{|c|}{$\mathrm{N}: 360$} \\
\hline & & Male & $\%$ Men & Female & $\%$ Women & Total & $\%$ Total & Male & $\%$ Men & Female & $\%$ Women & Total \\
\hline & & 193 & 45.95 & 227 & 54.05 & 420 & 100 & 207 & 57.5 & 153 & 42.5 & 360 \\
\hline \multirow[t]{5}{*}{ Age } & $>18$ & 5 & 1.19 & 6 & 1.43 & 11 & 2.62 & 0.00 & 0 & 0,00 & 0 & 0.00 \\
\hline & $18-35$ & 63 & 15.00 & 61 & 14.52 & 124 & 29.52 & 45 & 12.5 & 35 & 9.72 & 80 \\
\hline & $36-55$ & 68 & 16.19 & 75 & 17.86 & 143 & 34.05 & 90 & 25 & 68 & 18.89 & 158 \\
\hline & $56-75$ & 43 & 10.24 & 58 & 13.81 & 101 & 24.05 & 42 & 11.67 & 33 & 9.17 & 75 \\
\hline & Over 75 & 14 & 3.33 & 27 & 6.43 & 41 & 9.76 & 30 & 8.33 & 17 & 4.72 & 47 \\
\hline \multirow[t]{6}{*}{ Education } & Primary & 31 & 7.38 & 39 & 9.29 & 70 & 16.67 & 20 & 5.56 & 14 & 3.89 & 34 \\
\hline & Secundary & 72 & 17.14 & 107 & 25.48 & 179 & 42.62 & 50 & 13.89 & 43 & 11.94 & 93 \\
\hline & $\begin{array}{l}\text { Professional } \\
\text { training }\end{array}$ & 31 & 7.38 & 23 & 5.48 & 54 & 12.86 & 57 & 15.83 & 38 & 10.56 & 95 \\
\hline & University & 42 & 10.00 & 42 & 10.00 & 84 & 20.00 & 48 & 13.33 & 35 & 9.72 & 83 \\
\hline & $\begin{array}{l}\text { Master's } \\
\text { degree }\end{array}$ & 10 & 2.38 & 12 & 2.86 & 22 & 5.24 & 27 & 7.50 & 19 & 5.28 & 46 \\
\hline & $\mathrm{PhD}$ & 7 & 1.67 & 4 & 0.95 & 11 & 2.62 & 5 & 1.39 & 4 & 1.11 & 9 \\
\hline \multirow[t]{5}{*}{ Activity } & Freelance & 22 & 5.24 & 7 & 1.67 & 29 & 6.90 & 42 & 11.67 & 21 & 5.83 & 63 \\
\hline & Employee & 58 & 13.81 & 41 & 9.76 & 99 & 23.57 & 61 & 16.94 & 47 & 13.06 & 108 \\
\hline & $\begin{array}{c}\text { Public } \\
\text { worker }\end{array}$ & 32 & 7.62 & 23 & 5.48 & 55 & 13.10 & 31 & 8.61 & 20 & 5.56 & 51 \\
\hline & Student & 35 & 8.33 & 50 & 11.90 & 85 & 20.24 & 22 & 6.11 & 13 & 3.61 & 35 \\
\hline & Pensioner & 29 & 6.90 & 19 & 4.52 & 48 & 11.43 & 24 & 6.67 & 14 & 3.89 & 38 \\
\hline
\end{tabular}

Finally, seven of the questions asked to residents and visitors in relation to the Malaga brand were highlighted. The questions are divided into three blocks: a first block on knowledge and recognition of the brand, another on the development of the Malaga brand and a final block on the valuation and projection of the Malaga brand internally and externally. The questionnaire is in Appendix A.

\section{Results}

There are different strategies implemented for the city brand, and on numerous occasions the role of culture is presented as an innovative need to connect with the experience that tourists want to live on their trips [84], a culture that is present in the new image that is projected in the study of the Malaga brand.

The urban space as a cultural project was established in Malaga in the last decade [85], which allows in different cases the future of tourist cities to be redesigned [86] in a kind of improvement thanks to planning strategies that go through a process of open innovation in order to improve the tourist projection of Malaga through a better knowledge or even redesign of its promotional brand.

Of the 780 valid surveys, 420 were carried out on locals and 360 on visitors. As can be seen in Figure $4,78.8 \%$ of the questionnaires were completed by locals and $22.2 \%$ by people who visited the city.

Thus, the results will be presented below, differentiated according to the response categories inhabitants and visitors. They will be graphically represented separately, but in unified figures to improve the understanding of the results.

Figure 5 shows how, at first, the majority of locals are not familiar with the promotional brand Malaga. Of the 420 inhabitants surveyed, 270 claim not to know it, i.e., $64.4 \%$. The remaining 35.6\% (150 people) do know the brand without the need to show the graphic logo of the brand. 


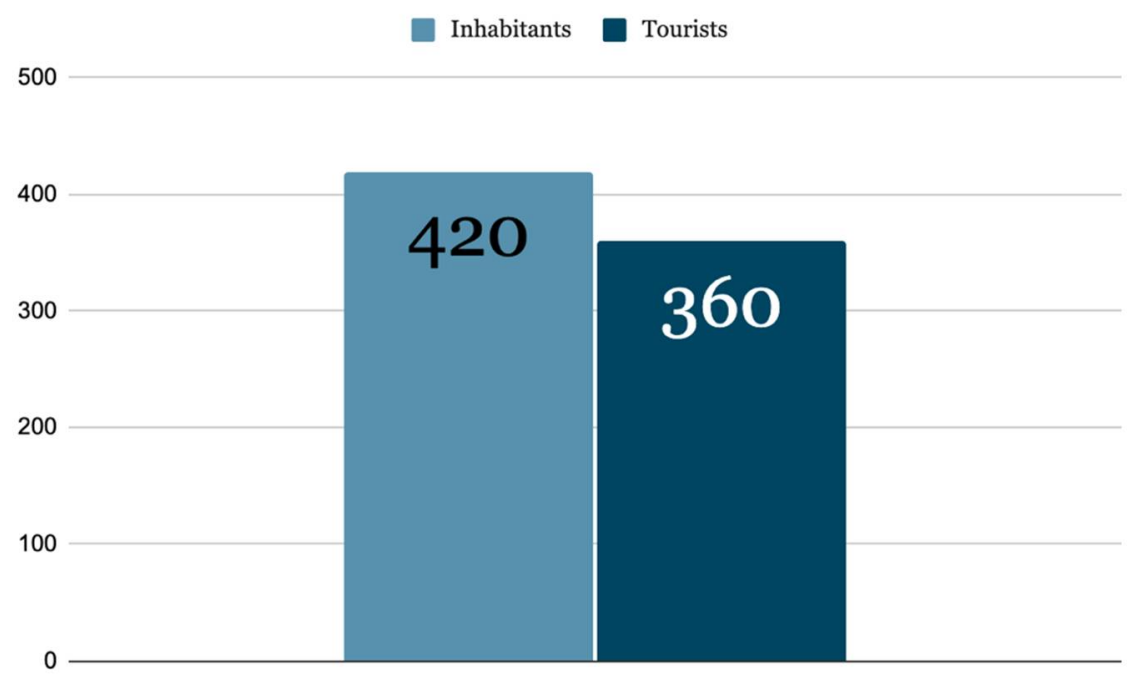

Figure 4. Distribution of surveys. Source: own elaboration.

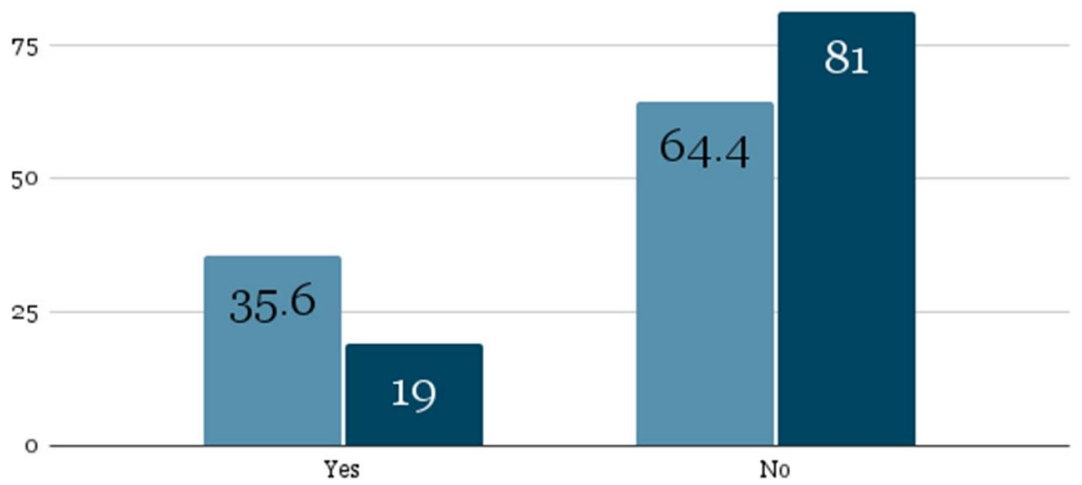

Figure 5. Do you know the brand Malaga? Source: own elaboration.

In order to introduce the next question, respondents are shown Figure 6, the graphic representation of the Malaga brand.

\section{Málaga}

Figure 6. Promotional brand Malaga. Used with permission from Turismo Málaga [87].

Once the logo is displayed, the percentages of recognition by locals and tourists change. Locals, when seeing the logo, recognise the promotional brand more easily: from $35.6 \%$ to $57.1 \%$. In the case of visitors, the change is smaller. When the brand is displayed, it goes from $19 \%$ to $29 \%$. In absolute values, of the 360 visitors interviewed, 69 know the brand and 105 identify it once it has been shown, as appears in Figure 7. 
80

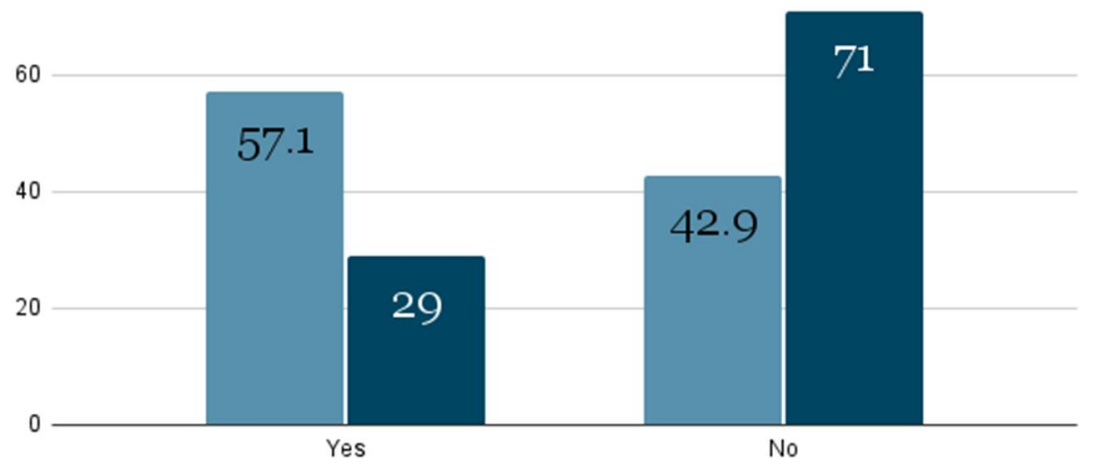

Figure 7. Identification of the Malaga brand. Source: own elaboration.

The third question refers to the sectors that can benefit from the Malaga brand. In this regard, the majority of locals consider that the tourism sector is the one that can benefit most from the existence of the Malaga promotional brand: $80 \%$ rate this benefit with a 5 on the Likert scale. Visitors, like locals, understand this to the same extent. However, unlike the locals, visitors also see the commercial sector ( $58 \%$ rate it as a 5 on the Likert scale), the food sector ( $52 \%$ rate it as a 5 on the Likert scale) and the ICT sector ( $38 \%$ rate it as a 5 on the Likert scale) as being able to benefit.

Similarly, taking into account that the fourth question is also measured on a Likert scale, $89 \%$ of the city's inhabitants consider that the Malaga brand is identified with tourism. This is undoubtedly the most highly regarded sector. It is followed, with $65 \%$, by leisure and $64 \%$ by culture. These are two sectors which are often understood together and which, according to the responses of those surveyed, are considered to have the same weight separately. Finally, $49 \%$ of the inhabitants of Malaga surveyed rated cruises as one of the products/services with which the Malaga brand is identified, with a score of 5 out of 5 on the Likert scale. Shopping was rated positively, with $39 \%$ of respondents giving it the highest rating. Languages, as a product/service, is barely valued with $14 \%$. At the other end of the scale, with less than $10 \%$, are the wine tourism sector ( $7 \%$ of respondents gave it a 5 on the Likert scale), the agri-food sector (5\%) and the manufactured products sector (3\%).

The visitors' perception of this fourth question is quite different. $82 \%$ of those surveyed rated 5 out of 5 on the Likert scale that the main identification of the Malaga promotional brand is tourism. The same score of 5 out of 5 is given to $58 \%$ for the leisure sector, $47 \%$ for the product/service museums and $42 \%$ for culture and gastronomy; $40 \%$ of tourists give the highest rating to cruises as a service that identifies with the brand; $25 \%$ consider that shopping as a product/service does benefit from the brand; in the case of the agri-food sector and manufactured products, both perceptions coincide: $5 \%$. None of the visitors consider that languages or wine tourism benefit from this brand.

Finally, questions 5 and 6 are shown together in Figure 8. The sixth question asks locals and visitors about the internal image projected by the Malaga brand at a national level. In this sense, the average response from locals is 59, while that of tourists is nine points higher: 68. The same occurs with the perception of the image projected at international level, locals give a rating of 67 and visitors nine points more: 76 . 

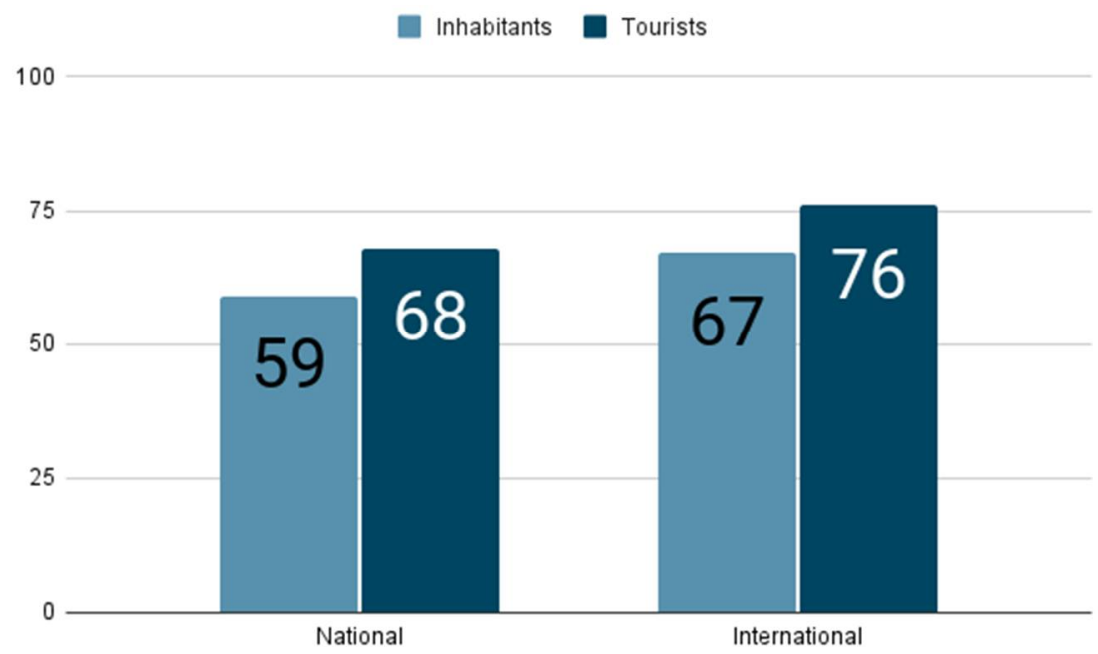

Figure 8. Perception of the image of Malaga. Source: own elaboration.

In the case of the last question, it was addressed exclusively to the 420 respondents who live in Malaga. Thus, a multiple-choice response was allowed among the eight options presented. The result is shown in Figure 9 and shows how, in the majority of cases, the City Council was identified as the necessary leader to develop and lead the building of the brand. With less than half of the responses (141 versus 292), the Malaga Provincial Council the leader. One third of the sectors considered as leaders is that of storekeepers and businesspeople. Thus, there is a hybridisation between the public sector (City Council and Provincial Council) and the private sector (storekeepers and businesspeople).

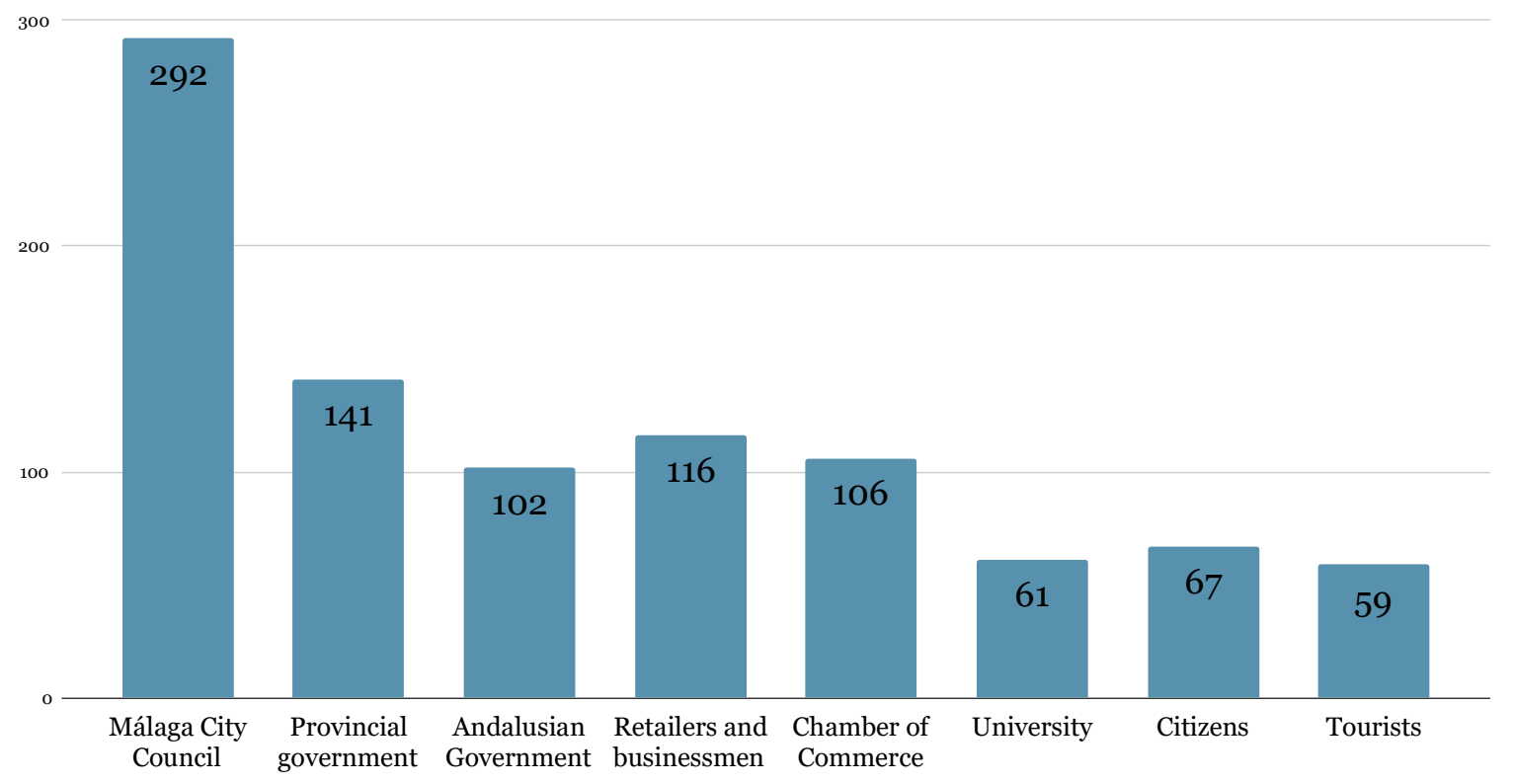

Figure 9. Who should lead the building of the Málaga brand? Source: own elaboration.

\section{Discussion}

As these brands become more and more recognised by local residents, it will help to create an image that will attract tourists to a destination. Especially if we know the perceptions of residents and tourists, we can reconcile both interests in terms of better management.

Brand communities can be especially useful for open communication processes. Members of these brand communities are seen as a particularly valuable source of innovation because they are passionate about the brand, they have experience with the products $[88,89]$ 
and because they support each other in solving problems and generating ideas for new products [90]. In this way, a diversity of images built on the same urban territory can derail the brand-building process even though, in many cases, an open consultation process has taken place [91].

Consumers understand brand innovation as the ability of companies and institutions to solve their problems in a new and valuable way. To the extent that citizens and visitors view the interests of city brands that focus on providing new and relevant solutions to customer needs as inferior to their own, customers are more likely to engage with them in a positive way $[92,93]$.

Applying the theory to what has been studied in this research, it is necessary to consider as a positive element the imbrication of open innovation to the management of city brands or territorial brands. In this case, it is necessary to recall the success of the Porto brand. As Dieguez and Conceição [74] point out, open innovation processes are essential for building territorial brands.

In this sense, the Sustainable Development Goals must be the pillar on which to build territorial brands or city brands. As they are elements that transcend cultures or borders, the SDGs are essential. We are talking about territorial brands, and as Therkelsen, James and Halkier [69] state, the market must play an important role, but it must be balanced to avoid contradictions.

As Castillo-Villar [94] points out, city branding is a concept that has its theoretical foundation in the adaptation of corporate branding. However, the implementation of corporate branding presents strong divergences, as in the case of a company it is completely different from the nature of urban management. This gap means that the translation of city branding theory into actual practice has limitations that administrations need to be aware of. Local governments need to move away from traditional strategic approaches [95] in order to build brands, so that other actors who can bring more depth to the process can take the lead.

\section{Conclusions and Recommendations}

The need for differentiation among tourist cities requires that they be recognised for their identity, as RQ 1 points to. Open innovation can and should be adjusted to the reality of the brands by considering them from the perspective of the resident and the tourist. In this way, a better management of the attributes and values conveyed by the brands can be designed, with the involvement of the cities' users.

The public management of data generated in cities has great innovative potential. Often, this information is sufficiently abundant and complex to function as "big data" in the various digital services provided by local administrations.

Innovative collaborative processes improve the use of resources and, in the long term, generate cost-saving capacity, reducing costs and saving resources over time. Through open innovation, sustainable and cost-effective services that take into account the interests of all stakeholders can be designed more easily.

The most significant impact of open innovation processes on the business models of municipalities is evident, specifically in the third sector associated with tourism, in relation to RQ 2. It improves the management of identity, competencies, knowledge and the process of developing services; municipalities must cease to be seen as a stable value chain.

Consequently, and answering RQ 3, public authorities that wish to transform their value creation and service delivery in a sustainable way, must [1] maintain a productive relationship with other public authorities and other external parties; [2] easily and safely exchange knowledge, skills and experience with others to improve internal processes and deliver services to citizens; and [3] engage with citizens and other stakeholders to co-create new services.

As limitations to the present paper, the authors have found a clear lack of literature, so it is important to develop this area of knowledge in order to further expand these concepts and, thus, to be able to carry out other comparative studies. 
Although the present study suggests that co-creation tools can be used by any other city in building its brand and generating a competitive advantage, there are limitations due to the nature of the research.

Finally, the recommendations proposed below require empirical validation, which opens up an opportunity for research.

Ultimately, the research proposes five recommendations for public administrations wishing to develop a city branding strategy from an open innovation perspective:

1. Aligning the objectives of the territory branding strategy with the Sustainable Development Goals sponsored by the United Nations. In particular, it is necessary to identify those that are consistent with the development of cities, without proposing unachievable objectives or those to which resources cannot be allocated by a city or territory.

2. Knowing and continuously consulting the opinion of citizens and visitors. Constant conversation is a basic element for the development of territorial brands. This is another part of open innovation processes.

3. Relying on the support and collaboration of the sources of knowledge to work on the brand itself: university, public companies, storekeepers, tourism sector, etc. All the information received from these areas will help to build the concept of the city brand in a more realistic way.

4. However, more information does not always mean making better decisions. Collaboration between areas must be total: qualified professionals from the areas consulted must be involved in the decision-making processes.

5. Encouraging constant co-creation. The development plans of the territorial brands must be alive, like society itself and all the elements of the proposed quadruple helix scheme. For this reason, the creation of monitoring institutes or offices with sufficient means to influence decision-making or issue binding opinions on the development of the brands is recommended.

Author Contributions: Conceptualization, E.C.-R. and G.Z.-A.; Data curation, E.C.-R., E.R.-R.d.1.C., G.Z.-A. and F.J.C.; Formal analysis, E.C.-R. and F.J.C.; Investigation, E.C.-R., E.R.-R.d.1.C., G.Z.-A. and F.J.C.; Methodology, E.R.-R.d.l.C. and F.J.C.; Project administration, E.C.-R. and E.R.-R.d.l.C.; Resources, E.C.-R., E.R.-R.d.I.C., G.Z.-A. and F.J.C.; Supervision, E.C.-R. and E.R.-R.d.l.C.; Validation, G.Z.-A.; Visualization, G.Z.-A. and F.J.C.; Writing—original draft, G.Z.-A. and F.J.C.; Writing—review \& editing, E.C.-R. and E.R.-R.d.l.C. All authors have read and agreed to the published version of the manuscript.

Funding: This research received no external funding.

Acknowledgments: Thanks to the University of Malaga for its research support.

Conflicts of Interest: The authors declare no conflict of interest.

\section{Appendix A}

Table A1. Questionnaire.

\begin{tabular}{|c|c|c|}
\hline & Question & Possible Answers \\
\hline 1 & $\begin{array}{l}\text { Do you know the promotional brand Malaga } \\
\text { [Figure 6]? }\end{array}$ & $\begin{array}{l}\text { Yes/No } \\
\text { Figure 6. Promotional brand Malaga. } \\
\text { Source: Ayuntamiento de Málaga [87]. }\end{array}$ \\
\hline 2 & $\begin{array}{l}\text { Do you identify the promotional brand Malaga? } \\
\text { (after showing the brand to the interviewee) }\end{array}$ & Yes/No \\
\hline 3 & $\begin{array}{l}\text { Which sectors can benefit from the promotional } \\
\text { brand Malaga? * }\end{array}$ & $\begin{array}{c}\text { Agriculture } \\
\text { Livestock } \\
\text { Food } \\
\text { Industrial } \\
\text { Commerce } \\
\text { Tourism } \\
\text { ICT }\end{array}$ \\
\hline
\end{tabular}


Table A1. Cont.

\begin{tabular}{|c|c|c|}
\hline & Question & Possible Answers \\
\hline 4 & $\begin{array}{l}\text { The promotional brand Malaga is identified with } \\
\text { the following products/services * }\end{array}$ & $\begin{array}{c}\text { Leisure } \\
\text { Culture } \\
\text { Museums } \\
\text { Gastronomy } \\
\text { Tourism } \\
\text { Cruises } \\
\text { Wine tourism } \\
\text { Languages } \\
\text { Agri-food } \\
\text { Manufactured products } \\
\text { Shopping }\end{array}$ \\
\hline 5 & $\begin{array}{l}\text { Rate the image projected of Malaga on a } \\
\text { national level }\end{array}$ & Average value of the answers on a scale of $0-100$ \\
\hline 6 & $\begin{array}{l}\text { Rate the image projected of Malaga on an } \\
\text { international level }\end{array}$ & Average value of the answers on a scale of $0-100$ \\
\hline 7 & $\begin{array}{l}\text { Question only addressed to residents: } \\
\text { Who do you think should lead the building of the } \\
\text { Malaga promotional brand? }\end{array}$ & $\begin{array}{c}\text { A choice of several answers is allowed between: } \\
\text { Ayuntamiento de Málaga (Malaga city council) } \\
\text { Diputación de Málaga (Malaga provincial council) } \\
\text { Junta de Andalucía (Andalusian regional government) } \\
\text { Storekeepers and business people } \\
\text { Chamber of commerce } \\
\text { University of Malaga } \\
\text { Citizens } \\
\text { Tourists }\end{array}$ \\
\hline
\end{tabular}

${ }^{*}$ Likert scale.

Questions 3 and 4 are measured through a Likert scale, whereby respondents indicate their perception within a measurement between zero (the value they consider the lowest) and 5 (for the response they consider the most appropriate).

\section{References}

1. Judd, D.R. El turismo urbano y la geografía de la ciudad. Eure 2003, 29, 51-62. [CrossRef]

2. Zhang, J.; Inbakaran, R.; Geographies, M.J.-T. Understanding community attitudes towards tourism and host-Guest interaction in the urban-Rural border region. Tour. Geogr. 2006, 8, 182-204. [CrossRef]

3. Cohen, E.; Cohen, S.A. A mobilities approach to tourism from emerging world regions. Curr. Issues Tour. 2015, 18, 11-43. [CrossRef]

4. Bouchon, F.A.L. Truly Asia and global city? Branding strategies and contested identities in Kuala Lumpur. Place Brand. Public Dipl. 2014, 10, 6-18. [CrossRef]

5. Paskaleva-Shapira, K.A. New paradigms in city tourism management: Redefining destination promotion. J. Travel Res. 2007, 46, 108-114. [CrossRef]

6. Davies, B. The role of quantitative and qualitative research in industrial studies of tourism. Int. J. Tour. Res. 2003, 5, 97-111. [CrossRef]

7. Michels, A. Citizen Participation in Local Policy Making: Design and Democracy. Int. J. Public Adm. 2012, 35, 285-292. [CrossRef]

8. Li, D.; Zhou, X.; Wang, M. Analyzing and visualizing the spatial interactions between tourists and locals: A Flickr study in ten US cities. Cities 2018, 74, 249-258. [CrossRef]

9. Muñiz-Martínez, N.; Cervantes-Blanco, M. Marketing de ciudades y "Place Branding". Pecunia Monográfico 2010, 1, 123-149. [CrossRef]

10. Stylidis, D.; Biran, A.; Sit, J.; Szivas, E.M. Residents' support for tourism development: The role of residents' place image and perceived tourism impacts. Tour. Manag. 2014, 45, 260-274. [CrossRef]

11. Cruz-Ruiz, E.; Ruiz-Romero de la Cruz, E.; Vázquez-Calderón, F.J. Sustainable tourism and residents' perception towards the brand: The case of Malaga (Spain). Sustainability 2019, 11, 292. [CrossRef]

12. Nunkoo, R.; Gursoy, D. Residents' support for tourism: An Identity Perspective. Ann. Tour. Res. 2012, 39, 243-268. [CrossRef]

13. Tsaur, S.H.; Chiu, Y.T.; Wang, C.H. The visitors behavioral consequences of experiential marketing: An empirical study on Taipei Zoo. J. Travel Tour. Mark. 2006, 21, 47-64. [CrossRef] 
14. Choe, J.Y.J.; Kim, S. Effects of tourists' local food consumption value on attitude, food destination image, and behavioral intention. Int. J. Hosp. Manag. 2018, 71, 1-10. [CrossRef]

15. Kim, H.K.; Lee, T.J. Brand equity of a tourist destination. Sustainability 2018, 10, 431. [CrossRef]

16. Sengel, T.; Karagoz, A.; Cetin, G.; Dincer, F.I.; Ertugral, S.M.; Balık, M. Tourists' Approach to Local Food. Procedia-Soc. Behav. Sci. 2015, 195, 429-437. [CrossRef]

17. Crouch, G.I.; Ritchie, J.R.B. Tourism, competitiveness, and societal prosperity. J. Bus. Res. 1999, 44, 137-152. [CrossRef]

18. Carli, R.; Dotoli, M.; Pellegrino, R. Multi-criteria decision-making for sustainable metropolitan cities assessment. J. Environ. Manag. 2018, 226, 46-61. [CrossRef]

19. Zerva, K.; Palou, S.; Blasco, D.; Donaire, J.A.B. Tourism-philia versus tourism-phobia: Residents and destination management organization's publicly expressed tourism perceptions in Barcelona. Tour. Geogr. 2019, 21, 306-329. [CrossRef]

20. Zenker, S.; Rütter, N. Is satisfaction the key $\alpha$ The role of citizen satisfaction, place attachment and place brand attitude on positive citizenship behavior. Cities 2014, 38, 11-17. [CrossRef]

21. Gilboa, S.; Jaffe, E.D.; Vianelli, D.; Pastore, A.; Herstein, R. A summated rating scale for measuring city image. Cities 2015, 44, 50-59. [CrossRef]

22. Stylidis, D. The Role of Place Image Dimensions in Residents' Support for Tourism Development. Int. J. Tour. Res. 2016, 18, 129-139. [CrossRef]

23. Beerli, A.; Martín, J.D. Factors influencing destination image. Ann. Tour. Res. 2004, 31, 657-681. [CrossRef]

24. Byon, K.K.; Zhang, J.J. Development of a scale measuring destination image. Mark. Intell. Plan. 2010, 28, 508-532. [CrossRef]

25. Chi, C.G.Q.; Qu, H. Examining the structural relationships of destination image, tourist satisfaction and destination loyalty: An integrated approach. Tour. Manag. 2008, 29, 624-636. [CrossRef]

26. Cherifi, B.; Smith, A.; Maitland, R.; Stevenson, N. Destination images of non-visitors. Ann. Tour. Res. 2014, 49, 190-202. [CrossRef]

27. Mak, A.H.N. Online destination image: Comparing national tourism organisation's and tourists' perspectives. Tour. Manag. 2017, 60, 280-297. [CrossRef]

28. Jutla, R.S. Visual image of the city: Tourists' versus residents' perception of Simla, a hill station in northern India. Tour. Geogr. 2010, 2, 404-420. [CrossRef]

29. Stylidis, D.; Sit, J.; Biran, A. An Exploratory Study of Residents' Perception of Place Image: The Case of Kavala. J. Travel Res. 2016, 55, 659-674. [CrossRef]

30. Cassia, F.; Vigolo, V.; Ugolini, M.M.; Baratta, R. Exploring city image: Residents' versus tourists' perceptions. TQM J. 2018, 30, 476-489. [CrossRef]

31. Deng, N.; Liu, J.; Dai, Y.; Li, H. Different cultures, different photos: A comparison of Shanghai's pictorial destination image between East and West. Tour. Manag. Perspect. 2019, 30, 182-192. [CrossRef]

32. Vargas, A. COVID-19 crisis: A new model of tourism governance for a new time. Worldw. Hosp. Tour. Themes 2020, 12, 691-699. [CrossRef]

33. Hristov, D.; Zehrer, A. Does distributed leadership have a place in destination management organisations? A policy-makers perspective. Curr. Issues Tour. 2019, 22, 1095-1115. [CrossRef]

34. Kozak, M.; Volgger, M.; Pechlaner, H. Destination leadership: Leadership for territorial development. Tour. Rev. 2014, 69, 169-172 [CrossRef]

35. Cruz-Ruiz, E.; Ruiz-Romero de la Cruz, E.; Zamarreño-Aramendia, G. Marca territorio y marca ciudad, utilidad en el ámbito del turismo. El caso de Málaga. Int. J. Sci. Manag. Tour. 2017, 3, 155-174.

36. San Eugenio, J. La marca de ciudad en la contemporaneidad. Poliantea 2014, 10, 11-27. [CrossRef]

37. Elizagarate Gutiérrez, V. Marketing de Ciudades. Estrategias Para el Desarrollo de Ciudades Atractivas y Competitivas en un Mundo Global; Ediciones Pirámide: Madrid, Spain, 2008.

38. Paz, S. Gestión estratégica y posicionamiento de ciudades. La marca de ciudad como vector para la proyección internacional. Rev. Venez. Gerenc. 2011, 10, 177-195. [CrossRef]

39. Zhang, K.; Chen, Y.; Lin, Z. Mapping destination images and behavioral patterns from user-generated photos: A computer vision approach. Asia Pac. J. Tour. Res. 2020, 25, 1199-1214. [CrossRef]

40. Saez, L. El Valor De La Marca Ciudad Como Elemento Diferenciador Y Generador de una Ventaja Competittive Sostenible; European Academic Publishers: Madrid, Spain, 2000; Available online: https:/ /elib.bsu.by/handle/123456789/51911 (accessed on 28 December 2021).

41. Sáez Vegas, L.; Mediano Serrano, L.; Elizagarate Gutiérrez, V. Creación y desarrollo de marca ciudad, análisis de los registros de marca de las principales ciudades españolas. Rev. Dir. Adm. Empres. Enpresen Zuzendaritza Adm. Aldizkaria 2011, 18, 125-156.

42. Govers, R.; Go, F. Place Branding: Glocal, Virtual and Physical Identities, Constructed, Imagined and Experienced; Springer: Berlin/Heidelberg, Germany, 2016; ISBN 9780230247024.

43. Rupo, D.; Perano, M.; Centorrino, G.; Vargas-Sanchez, A. A framework based on sustainability, open innovation, and value cocreation paradigms-A case in an Italian maritime cluster. Sustainability 2018, 10, 729. [CrossRef]

44. Yigitcanlar, T.; Kamruzzaman, M.; Buys, L.; Ioppolo, G.; Sabatini-Marques, J.; da Costa, E.M.; Yun, J.H.J. Understanding 'smart cities': Intertwining development drivers with desired outcomes in a multidimensional framework. Cities 2018, 81, 145-160. [CrossRef] 
45. Zamarreño-Aramendia, G.; Cristòfol, F.J.; De-San-eugenio-vela, J.; Ginesta, X. Social-Media Analysis for Disaster Prevention: Forest Fire in Artenara and Valleseco, Canary Islands. J. Open Innov. Technol. Mark. Complex. 2020, 6, 169. [CrossRef]

46. Hjalager, A.M.; Nordin, S. User-driven Innovation in Tourism-A Review of Methodologies. J. Qual. Assur. Hosp. Tour. 2011, 12, 289-315. [CrossRef]

47. Tejada, P.; Moreno, P. Patterns of innovation in tourism 'Small and Medium-size Enterprises'. Serv. Ind. J. 2013, 33, 749-758. [CrossRef]

48. Iglesias-Sánchez, P.P.; Correia, M.B.; Jambrino-Maldonado, C. Challenges of Open Innovation in the Tourism Sector. Tour. Plan. Dev. 2017, 16, 22-42. [CrossRef]

49. Boes, K.; Buhalis, D.; Inversini, A. Conceptualising Smart Tourism Destination Dimensions. In Information and Communication Technologies in Tourism 2015; Springer: Cham, The Netherlands, 2015.

50. Lalicic, L. Open innovation platforms in tourism: How do stakeholders engage and reach consensus? Int. J. Contemp. Hosp. Manag. 2018, 30, 2517-2536. [CrossRef]

51. Pikkemaat, B.; Peters, M. Open Innovation: A Chance for the Innovation Management of Tourism Destinations? In Open Tourism; Springer: Berlin/Heidelberg, Germany, 2016; pp. 153-169. [CrossRef]

52. van Ham, P. The Rise of the Brand State: The Postmodern Politics of Image and Reputation. Foreign Aff. 2001, 80. [CrossRef]

53. López Lita, R.; Benbelloch, M. De la marca comercial a la marca territorio. Recerca 2005, 5, 87-100.

54. Acharya, A.; Rahman, Z. Place branding research: A thematic review and future research agenda. Int. Rev. Public Nonprofit Mark. 2016, 13, 289-317. [CrossRef]

55. Boisen, M.; Terlouw, K.; Groote, P.; Couwenberg, O. Reframing place promotion, place marketing, and place branding-Moving beyond conceptual confusion. Cities 2018, 80, 4-11. [CrossRef]

56. Fyhri, A.; Jacobsen, J.K.S.; Tømmervik, H. Tourists' landscape perceptions and preferences in a Scandinavian coastal region. Landsc. Urban Plan. 2009, 91, 202-211. [CrossRef]

57. Kavaratzis, M.; Hatch, M.J. The Elusive Destination Brand and the ATLAS Wheel of Place Brand Management. J. Travel Res. 2019, 60, 3-15. [CrossRef]

58. Stylidis, D.; Belhassen, Y.; Shani, A. Three Tales of a City: Stakeholders' Images of Eilat as a Tourist Destination. J. Travel Res. 2015, 54, 702-716. [CrossRef]

59. Vanolo, A. City Branding: The Ghostly Politics of Representation in Globalising Cities; Rutledge: New York, NY, USA, $2017 ;$ pp. 1-207. [CrossRef]

60. Yun, J.; Won, D.; Technology, K.P.O.I. Dynamics from open innovation to evolutionary change. J. Open Innov. Technol. Mark. Complex. 2016, 2, 7. [CrossRef]

61. Yun, J.J.; Nadhiroh, I.M.; Jung, W.Y. The relationship between open innovation, entrepreneurship, and introduction of new business models in Korean and Indonesian information technology enterprises. Korean Soc. Sci. J. 2013, 40, 81-99. [CrossRef]

62. Yun, J.H.J.; Zhao, X.; Jung, K.H.; Yigitcanlar, T. The culture for open innovation dynamics. Sustainability 2020, 12, 76. [CrossRef]

63. Yun, J.H.J.; Liu, Z. Micro- and macro-dynamics of open innovation with a Quadruple-Helix model. Sustainability 2019, 11, 3301. [CrossRef]

64. Leydesdorff, L.; Park, H.W. Can synergy in Triple Helix relations be quantified? A review of the development of the Triple Helix indicator. Triple Helix 2014, 1, 4. [CrossRef]

65. Gouvea, R.; Kassicieh, S.; Montoya, M.J.R. Using the quadruple helix to design strategies for the green economy. Technol. Forecast. Soc. Chang. 2013, 80, 221-230. [CrossRef]

66. Ishaq, M.I.; Di Maria, E. Sustainability countenance in brand equity: A critical review and future research directions. J. Brand Manag. 2020, 27, 15-34. [CrossRef]

67. Marsden, T.; Smith, E. Ecological entrepreneurship: Sustainable development in local communities through quality food production and local branding. Geoforum 2005, 36, 440-451. [CrossRef]

68. Maheshwari, V.; Vandewalle, I.; Bamber, D. Place branding's role in sustainable development. J. Place Manag. Dev. 2011, 4 , 198-213. [CrossRef]

69. Therkelsen, A.; James, L.; Halkier, H. Place branding for sustainable development: The role of tourism in sustainable place branding strategies. In Marketing Countries, Places, and Place-Associated Brands; Edward Elgar Publishing: Cheltenham, UK, 2021; pp. 319-336.

70. Rehan, R.M. Urban branding as an effective sustainability tool in urban development. HBRC J. 2014, 10, 222-230. [CrossRef]

71. Insch, A. Positioning cities: Innovative and sustainable strategies for city development and transformation. Place Brand. Public Dipl. 2014, 10, 249-252. [CrossRef]

72. Löfgren, O. Catwalking the city. In Branding Chinese Mega-Cities Policies; Edward Elgar Publishing: Cheltenham, UK, 2014; pp. 195-206. [CrossRef]

73. Ojasalo, J.; Kauppinen, H. Collaborative Innovation with External Actors: An Empirical Study on Open Innovation Platforms in Smart Cities. Technol. Innov. Manag. Rev. 2016, 6, 49-60. [CrossRef]

74. Dieguez, T.; Conceiçã, O. Innovative destination branding: "porto". In Proceedings of the Smart Innovation, Systems and Technologies; Springer: Singapore, 2020; Volume 171, pp. 131-140.

75. Carayannis, E.G.; Campbell, D.F.J. “Mode 3" and "Quadruple Helix": Toward a 21st century fractal innovation ecosystem. Int. J. Technol. Manag. 2009, 46, 201-234. [CrossRef] 
76. Schultz, D.E.; Schulz, H.F. How to Build a Billion Dollar Business-to-Business Brand. Mark. Manag. 2000, 9, 22.

77. Sebastián Morillas, A.; Ayestarán Crespo, R.; Rangel Pérez, C. Planifición Estratégica y Gestión. Conectando Con el Consumidor; ESIC: Madrid, Spain, 2012

78. Spengler, C.; Müller, J. Marktkommunikation im wandel: Welcher marken-Touchpoint zählt. In Community Marketing: Wie Unternehmen in Sozialen Netzwerken Werte Schaffen; Kaul, H., Steimann, C., Eds.; Schäffer Poeschel: Munich, Germany, 2008; pp. 217-232.

79. McLuhan, M.; Fiore, Q. The Medium is the Messege; Allen Lane: London, UK, 1967.

80. Wiyono, B.; Rahmanto, A.; Utari, P. The Role of Stakeholders in the City Branding Policy "Madiun Karismatik" Madiun City Government. Int. J. Multicult. Multireligious Underst. 2021, 8, 510-515. [CrossRef]

81. Meneses, J.; Rodríguez, D. El cuestionario y la entrevista; UOC (Universitat Oberta de Catalunya): Barcelona, Spain, 2011. Available online: https:/ / femrecerca.cat/meneses/publication/cuestionario-entrevista/cuestionario-entrevista.pdf (accessed on 28 December 2021).

82. Instituto Geográfico Nacional. Available online: https://www.ign.es/ (accessed on 28 December 2021).

83. Ayuntamiento de Málaga. Available online: https://www.malaga.eu/recursos/ayto/distritos/distritosd_municipales.html (accessed on 28 December 2021)

84. Ozer, S.U. The role of culture in city branding. In Advertising and Branding: Concepts, Methodologies, Tools, and Applications; IRMA International: Hershey, PA, USA, 2017; pp. 1125-1142. ISBN 9781522517948.

85. Jiménez, R.; Royo Naranjo, M.L. Destino Costa del Sol: La invención de un modelo turístico cuestionado: Mito, historia y realidad de un proyecto para el S. XX. In Territ DEL Tur El Imaginario Turístico y la Construccíon del Paisaje Contemporáneo 2014; Fava, N., García Vergara, M., Eds.; Viguera Editores: Girona, Spain, 2014; pp. 631-643.

86. Puig, T. Marca Ciudad. 2009. Available online: anchecata.colmich.edu.mx (accessed on 28 December 2021).

87. Málaga turismo. Available online: www.malagaturismo.com (accessed on 28 December 2021).

88. McAlexander, J.H.; Schouten, J.W.; Koenig, H.F. Building brand community. J. Mark. 2002, 66, 38-54. [CrossRef]

89. Sawhney, M.; Verona, G.; Prandelli, E. Collaborating to create: The Internet as a platform for customer engagement in product innovation. J. Interact. Mark. 2005, 19, 4-17. [CrossRef]

90. Herstatt, C.; Sander, J.G. Online-Kundeneinbindung in den frühen Innovationsphasen. In Produktentwicklung Mit Virtuellen Communities; Gabler Verlag: Wiesbaden, Germany, 2004; pp. 99-119.

91. Ruiz-Romero de la Cruz, E.; Cruz-Ruiz, E.; Zamarreño-Aramendia, G. Rutas enológicas y desarrollo local. Presente y futuro en la provincia de Málaga. Int. J. Sci. Manag. Tour. 2017, 3, 283-310.

92. Eisingerich, A.B.; Rubera, G. Drivers of brand commitment: A cross-national investigation. J. Int. Mark. 2010, 18, 64-79. [CrossRef]

93. Elia, G.; Messeni Petruzzelli, A.; Urbinati, A. Implementing open innovation through virtual brand communities: A case study analysis in the semiconductor industry. Technol. Forecast. Soc. Chang. 2020, 155, 119994. [CrossRef]

94. Castillo-Villar, F.R. Alcances y límites de la marca ciudad en la gestión de la imagen de la ciudad. Rev. Venez. Gerenc. 2016, 21, 157-171. [CrossRef]

95. Lindstedt, J. A deliberately emergent strategy-A key to successful city branding. J. Place Manag. Dev. 2015, 8, 90-102. [CrossRef] 